\title{
12
}

\section{Insect-Based Bioconversion: Value from Food Waste}

\author{
Trevor M. Fowles and Christian Nansen
}

\section{Introduction}

As detritivores and herbivores, the diversity of insect species includes groups highly specialized in their ability to thrive on different organic substrates as food sources. Some of these substrates resemble food wastes from agriculture and food processing industries. In the literature, this is referred to as insects-based "bioconversion" and represents an economically viable method for turning large quantities of food waste into valuable materials - including feed for animals (insect biomass as a supplement added to animal feed), food for people, secondary industrial compounds (biofuel, lubricants, pharmaceuticals, dyes, etc.), and the leftover food waste can be used as organic matter and nutrient-rich

\footnotetext{
T. M. Fowles $(\bowtie) \cdot$ C. Nansen

Department of Entomology and Nematology, University of California, Davis, CA, USA e-mail: tmfowles@ucdavis.edu

C. Nansen

e-mail: chrnansen@ucdavis.edu

(C) The Author(s) 2020 
soil amendments. Consequently, the services rendered from insectbased bioconversion provide marketable solutions for reducing food waste that are fiscally manageable, modest both in space and energy requirements, environmentally friendly, associated with real market/ commercial opportunities, and yielding higher feed conversion ratios than conventional livestock ( $\mathrm{Li}$ et al. 2013; van Huis and Oonincx 2017). Though a relatively nascent industrial sector, mass production of insects for feed and secondary products is a rapidly growing enterprise with significant potential for growth (Dossey et al. 2016; van Huis and Oonincx 2017). Presently, only a few insect species are commercially used for insect-based bioconversion of food waste, with black soldier fly larvae (Hermetia illucens L.) being the most commonly used species (Wang and Shelomi 2017). This is juxtaposed by the immense diversity of insects adapted to a wide range of food sources and therefore likely capable of providing effective bioconversion of a wide range of food waste materials. Considering the diversity of food waste streams generated from numerous crop varieties and their by-products from downstream processing, there appears to be ample opportunity for exploration of optimized combinations of food wastes-to-insect pairings to maximize both bioconversion and insect biomass production. In this chapter, we argue better food waste-to-insect pairings and selective breeding of insects are needed to increase capacity of using insects-based bioconversion of food waste. In addition, we provide both theoretical and practical solutions (businesses), and regulatory hurdles relating to insect-based bioconversion of food waste.

\section{The Case for Insects-Why Bioconversion of Food Waste?}

insect-based bioconversion of food waste is the controlled breakdown of an initial feedstock (food waste) into insect biomass and frass (waste residuals) (Barry 2004), with the latter consisting of predominantly insect frass and to a lesser extent, shed exoskeletons, dead insect parts, and potentially uneaten feedstock. The process of insect-based 
bioconversion of food waste mirrors the natural breakdown of organic matter in ecosystems ( $\mathrm{Lim}$ et al. 2016). In such systems, naturally occurring insects, earthworms, a wide range of other invertebrates, fungi, and bacteria colonize and break down food waste, converting the nutrients for their own metabolic and reproductive needs. Under controlled conditions, the species responsible for the decomposition process can be regulated and the ambient conditions can be optimized to favour the growth and bioconversion by the given species performing the service. Importantly, value may be produced at multiple steps in the bioconversion process (Barry 2004). For instance, value can be gained from the elimination of the initial waste itself (Mutafela 2015) (disposal fees), sales of insect biomass for food and feed (Anankware et al. 2015), sales from fractionated secondary products (Zheng, $\mathrm{Li}$, et al. 2012), and sales of the remaining bioconverted waste for soil amendments (Suantika et al. 2017). Industrial insect rearing can efficiently turn many tonnes of food waste feedstock into valuable products, with some sources suggesting most food waste can be diverted to insect-based bioconversion (Ortiz et al. 2016; Veldkamp et al. 2012). Currently, Agriprotein's South African facility has the capacity to process 72 megagram $(\mathrm{Mg})$ tonnes of food waste each day, in turn generating $16 \mathrm{Mg}$ of "insect meal" (dried powder from ground insect biomass), $9 \mathrm{Mg}$ of insect oil, and $88 \mathrm{Mg}$ of fertilizer (www.agriprotein.com). Agriprotein uses black soldier fly for its food waste bioconversion and is looking into using other species as they expand. They are one of several companies in the rapidly expanding insect-based bioconversion sector, with others including Ynsect (www.ynsect.com), Nextalim (www.nextalim.com), UNIQUE (www. gzunique.com.cn), and Alapre (www.insectmeal.com.co).

Commercialization of insect-based bioconversion represents a promising shift in providing alternative options for food waste reduction (Nyakeri et al. 2017; Wang and Shelomi 2017), as the industrial production of insects requires significant quantities of cheap, reliable feedstock (Ortiz et al. 2016). With supplies of global food waste estimated at 1.3 billion tonnes and growing (Ambuko 2014; FAO 2017), and demands for protein, biofuels, and fertilizers increasing (Parfitt et al. 2010), businesses adopting insect-based bioconversion make economic sense (Barry 2004). Moreover, insect-based bioconversion of otherwise 
disposable food wastes provides a much-needed link for recirculating nutrients and resources from consumers back into agricultural supply chains. With consumers evermore concerned about the environmental profile of goods, insect-based bioconversion of waste is a marketable asset that may appeal to the sustainably minded customer (D'Souza et al. 2007). On a philosophical level, the concept of insect-based bioconversion hinges on the notion of completely re-thinking the concept of "food waste". In the Webster's English Dictionary, "waste" is defined as "an unwanted by-product". The Food and Agriculture Organization of the United Nations makes a further distinction between "food loss" (early stages of the food supply chain) and "food waste" (later in the food supply chain) (FAO 2017). The concept of insect-based bioconversion means that by-products from one food production system become the input in bioconversion systems, so the concept of "waste" and "loss" really cannot be applied. Thus, the trend trail-blazed by insect-based bioconversion and described in this chapter represents a re-thinking of nutrient and resource flows within and among food production systems, and it is expected to become a critical part of more sustainable food production systems in the twenty-first century.

\section{Waste-to-Insect Pairings}

While the most commonly used species of bioconverters may be very suitable in some situations, one species cannot adequately capitalize on the immense diversity of food waste streams (Lardé 1990; Smetana et al. 2016). Within the diversity of insects, there are undoubtedly species with specific attributes that make them uniquely suited as bioconverters of a highly specialized food waste. To optimize pairings of insect species and food waste, one must consider a combination of abiotic interactions and functional traits of the insect for handling the waste. Abiotic attributes are non-living chemical and physical characteristics of the food waste (i.e. moisture content, phenolics, nutrient load, etc.). Whereas, functional attributes of insects include: feeding behaviour, morphology (i.e. large mandibles (mouth part) for masticating, soft bodies for moving through substrates, behavioural avoidance of poor 
egg laying sites), development time, ability to resist diseases, and a range of other attributes. It is the combination of these abiotic and functional attributes that allow some insects to be well suited for bioconversion of waste, while rendering others as maladapted (Fig. 12.1).

For example, vegetative food wastes can be fed to both black soldier fly larvae and mealworm larvae ( $\mathrm{Li}$ et al. 2013; Manurung et al. 2016), but this waste is too low in protein content for housefly larvae (Hogsette 1992). Conversely, restaurant and kitchen wastes containing meat are well suited for housefly and black soldier fly larvae, but are too wet for mealworms, which can get moisture directly from the air and thus perform optimally in drier wastes (Cheng et al. 2017). Further, black soldier fly larvae tolerance of wet wastes and high temperatures (from bacterial and colony metabolism) allow them to capitalize on many waste streams (Table 12.1). But husbandry practices also require specific lighting for breeding, the flies are intolerant to temperature drops, and perform poorly in some low nutrient wastes (beet pulp
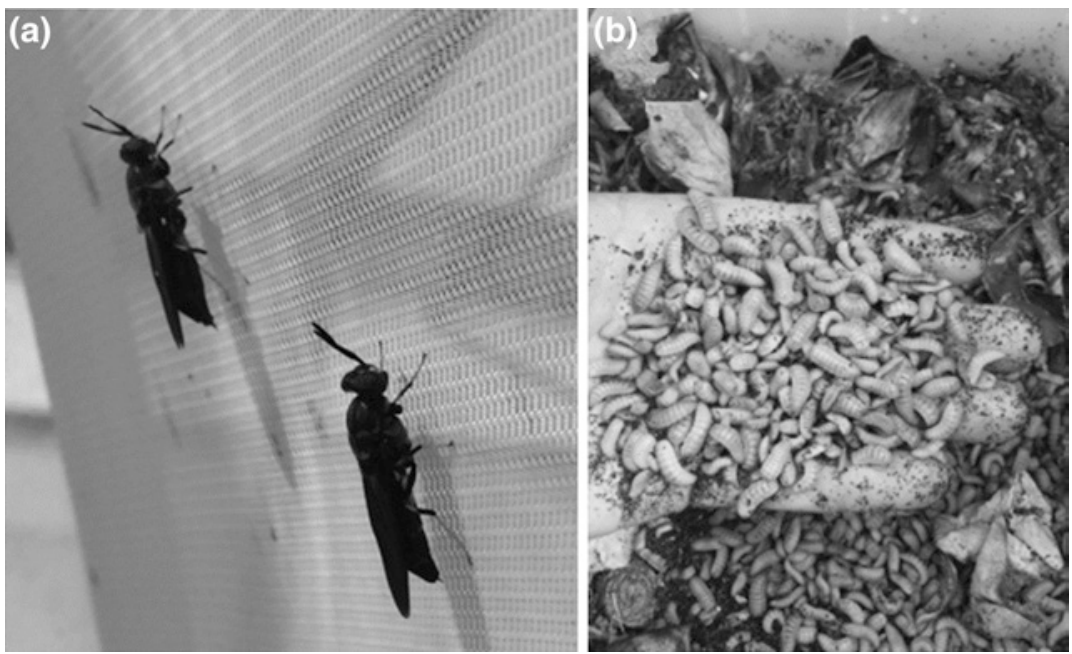

Fig. 12.1 Two adult black Soldier flies. Adults live only a couple of weeks, while they mate and lay eggs (a). Black soldier fly larvae on restaurant waste (b). Once growing to their full size, larvae exhibit self-extraction behaviours and move away from their food source 
Table 12.1 Some insects used for bioconversion, the different wastes that they can be fed, and the final products

\begin{tabular}{|c|c|c|c|c|}
\hline Species & $\begin{array}{l}\text { Organic } \\
\text { wastes }\end{array}$ & Country & $\begin{array}{l}\text { Bioconversion } \\
\text { output }\end{array}$ & Reference \\
\hline \multirow{11}{*}{$\begin{array}{l}\text { Black soldier } \\
\text { fly } \\
\text { (Hermetia } \\
\text { illucens) }\end{array}$} & $\begin{array}{l}\text { Rice straw, } \\
\text { restaurant } \\
\text { waste }(3: 7)\end{array}$ & China & Biofuel & $\begin{array}{l}\text { Zheng, Hou, } \\
\text { et al. (2012) }\end{array}$ \\
\hline & Rice straw & Indonesia & Biomass & $\begin{array}{l}\text { Manurung } \\
\text { et al. (2016) }\end{array}$ \\
\hline & $\begin{array}{l}\text { Coffee pulp, } \\
\text { husk }\end{array}$ & $\begin{array}{l}\text { El Salvador, } \\
\text { Indonesia }\end{array}$ & $\begin{array}{l}\text { Biomass, } \\
\text { fertilizer }\end{array}$ & $\begin{array}{l}\text { Lardé (1990), } \\
\text { Suantika } \\
\text { et al. (2017) }\end{array}$ \\
\hline & $\begin{array}{l}\text { Waste from } \\
\text { pears, } \\
\text { banana, and } \\
\text { cucumber } \\
(5: 3: 2)\end{array}$ & Sweden & Biomass & $\begin{array}{c}\text { Mutafela } \\
\text { (2015) }\end{array}$ \\
\hline & Corn stover & China & $\begin{array}{l}\text { Biofuel, soil } \\
\text { amendment }\end{array}$ & $\begin{array}{l}\text { Wang et al. } \\
(2017)\end{array}$ \\
\hline & Corncob & China & Biofuel & Li et al. (2015) \\
\hline & Sorghum & United States & Biomass & $\begin{array}{l}\text { Tinder et al. } \\
(2017)\end{array}$ \\
\hline & Cowpea & United States & Biomass & $\begin{array}{l}\text { Tinder et al. } \\
\text { (2017) }\end{array}$ \\
\hline & Cassava peel & Indonesia & Biomass & $\begin{array}{l}\text { Supriyatna } \\
\text { et al. (2016) }\end{array}$ \\
\hline & $\begin{array}{l}\text { Vegetable } \\
\text { trimmings, } \\
\text { spent coffee } \\
\text { grounds, and } \\
\text { tea leaves }\end{array}$ & $\begin{array}{c}\text { United States, } \\
\text { Hong Kong }\end{array}$ & Biomass & Cheng (2016) \\
\hline & $\begin{array}{l}\text { Vegetables, } \\
\text { peels of yam, } \\
\text { cassava, } \\
\text { plantain }\end{array}$ & Ghana & Biomass & Bonso (2013) \\
\hline $\begin{array}{l}\text { Housefly } \\
\text { (Musca } \\
\text { domestica) }\end{array}$ & $\begin{array}{l}\text { Restaurant } \\
\text { waste }(70 \%) \\
\text { Corn silage, } \\
\text { sawdust } \\
(30 \%)\end{array}$ & China & $\begin{array}{l}\text { Biomass, } \\
\text { biofuel, } \\
\text { fertilizer }\end{array}$ & $\begin{array}{l}\text { Niu et al. } \\
\text { (2017) }\end{array}$ \\
\hline $\begin{array}{l}\text { Codling moth } \\
\text { (Cydia } \\
\text { pomonella) }\end{array}$ & $\begin{array}{l}\text { Starch and } \\
\text { cheese } \\
\text { wastewater } \\
\text { sludge }\end{array}$ & Canada & Biomass & $\begin{array}{c}\text { Brar et al. } \\
(2008)\end{array}$ \\
\hline
\end{tabular}


Table 12.1 (continued)

\begin{tabular}{|c|c|c|c|c|}
\hline Species & $\begin{array}{l}\text { Organic } \\
\text { wastes }\end{array}$ & Country & $\begin{array}{l}\text { Bioconversion } \\
\text { output }\end{array}$ & Reference \\
\hline $\begin{array}{l}\text { Cambodian } \\
\text { field crickets } \\
\text { (Teleogryllus } \\
\text { testaceus) }\end{array}$ & $\begin{array}{l}\text { Cassava plant } \\
\text { tops, spent } \\
\text { grain, mung } \\
\text { bean sprout } \\
\text { waste, field } \\
\text { weeds }\end{array}$ & Cambodia & Biomass & $\begin{array}{l}\text { Miech et al. } \\
(2016)\end{array}$ \\
\hline \multirow{2}{*}{$\begin{array}{l}\text { Yellow } \\
\text { Mealworm } \\
\text { (Tenebrio } \\
\text { molitor) }\end{array}$} & $\begin{array}{l}\text { Wheat straw, } \\
\text { bruised cab- } \\
\text { bage leaves }\end{array}$ & China & Biomass & \\
\hline & Corn stover & China & Biofuel & $\begin{array}{l}\text { Wang et al. } \\
\text { (2017) }\end{array}$ \\
\hline
\end{tabular}

(Smetana et al. 2016)). This combination of abiotic interactions and functional traits of the flies translate to actual economic trade-offs, as drying food wastes and using special equipment (lights) add costs to commercial operations. As such, considering appropriate waste-to-insect pairings is a significant component in using insects in food waste reduction. Table 12.1 illustrates examples of appropriate waste-to-insect pairings, while not an exhaustive list, it highlights the extent to which more insects should be studied for their potential bioconversion performance. Table 12.1 also includes products of economic value generated from bioconversion, with the inclusion of less commonly used insect species.

\section{Selective Breeding}

Due to their short lifespans, high reproductive rates, and variable genetic expression, insect adaptation (evolution) may occur within economically relevant time scales (Jensen et al. 2017). When adaptation is controlled by humans, the process is referred to as artificial selection or selective breeding and will play an important role in developing/engineering insect lines for bioconverting specific food wastes (Jensen et al. 2017). For example, some by-products of food processing are high in plant defensive chemicals and are largely inedible. 
These "recalcitrant" food wastes may be high in tannins and phenolics (for instance, the chemicals partially responsible for the specific/unique tastes associated with wine, cranberries, coffee, chocolate, and cinnamon) and are difficult to bioconvert using insects. These chemicals are plant adaptations evolved to repel or even kill herbivores (van Dyk et al. 2013). However, studies focusing on insect-plant defensive interactions have demonstrated insects can be adapted to detoxify these chemicals (Carroll et al. 1998; De Jong and Bijma 2002). Using selective breeding, insects could be bred to overcome defensive chemicals found in recalcitrant wastes and thus allow for bioconversion of troublesome food wastes (e.g. wine and olive pomace). Other examples of insect breeding may include, improving germlines to increase yields of secondary products (oils and pharmaceuticals) (Li et al. 2012), larger body size (Jensen et al. 2017), and shifts to novel food sources (Alves et al. 2016).

Selective breeding in industrial mass production of insect occurs actively or passively (Jensen et al. 2017). Passive selective breeding involves permitting mated females to self-select waste oviposition (eggs laying) sites across generations. For breeding and bioconversion operations, female self-selection may pose a cost-efficient method for capitalizing on insect instinctive (innate) survival behaviours (Nansen et al. 2016). For example, silkworm "innate recognition templates" are programmed to specific chemical cues that indicate the best food for her offspring even after thousands of years of domestication (Garlapow et al. 2015). Active selective breeding involves forming separate lines for each waste and using inbreeding, linebreeding, and outcrossing to control gene expression (Jensen et al. 2017). In general, active selective breeding requires more maintenance and containment and therefore can be cost prohibitive for some operations. However, active selective breeding is more controlled, which may appeal to capital intensive operations, and it represents an opportunity to develop and commercialize specific insect strains. In conclusion, insect breeding for more efficient food waste reduction is still in a preliminary phase academically, which contrasts to the proprietary lines already used by commercial enterprises. Nevertheless, as businesses continue to develop around industrial insect production there will be more funding and research interest in advanced insect breeding programs. 


\section{Business Processes}

Food waste may be viewed as a problem by some, but others view it as an appealing opportunity for business. The last two decades have seen an explosion of growth in businesses using insects to convert food waste (Table 12.2). Yet, businesses centred on the mass production of insects have existed for centuries (honey bees, silk moths, lacquer bugs) (van Huis 2013). Additionally, many businesses developed in second half of the twentieth century selling insects for biocontrol, medical research, and for supporting the pet trade (Ortiz et al. 2016). Drawing on research and methods developed for mass production of insects for other purposes, new companies are finding significant opportunities producing insects for feed and food. An indispensable component for these businesses is acquisition of inexpensive, abundant, and consistent sources of feedstock, and for many the preferred and economical choice is food waste.

In the following, we describe the basic design of mass production of insects for bioconversion, with different steps for producing valuable materials (Fig. 12.2, steps 1-11). Operations begin with an incoming food waste feedstock (1). Food waste feedstock may require preprocessing before it can be used as feedstock for the given insects (2). Some pre-consumer food wastes like juice pulps are already processed and can therefore go directly into the bioconversion process. Once the feedstock is ready, insect inoculum is added either as eggs or as small immatures (3). For all insect species, most of the growth and bioconversion occurs during the immature stages. To optimize biomass production, the ideal harvesting time is during late (well-developed) immature stages. Harvesting/extraction (4) may be done by mechanically sifting immatures from frass; however, some insects have selfextraction behaviours which allow them to be collected by controlling their evacuation routes. The sifted frass may then be further broken down via microbial decay (10) or mixed with additives and packaged as a fertilizer (7). Depending on the business, populations of extracted insects may be sold live (5) or further refined into valuable commodities such as biodiesel, defatted insect meal, pharmaceuticals, etc. (6-7). 


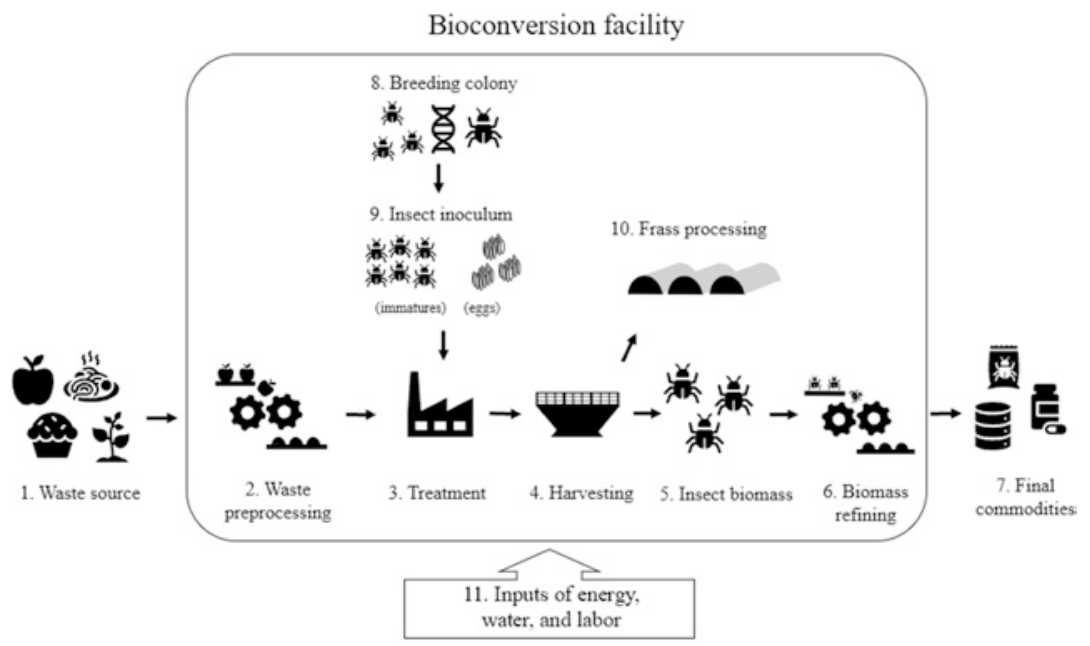

Fig. 12.2 Typical business process for insect-based bioconversion of food waste. Note that value can be extracted from both the elimination of waste and downstream materials, such as insect protein (biomass), oils, frass, and pharmaceutical ingredients (Image is modified from an original design by www.eawag.ch/ and licensed under CC BY 2.0.)

In addition, each of these steps may require external inputs of electricity, water, labour, etc. (11). It should be noted that there is a range of opportunities provided within the production chain, from highvalued small-volume products to low-value bulk commodities. Below, we briefly review some of the possible revenue streams from insect bioconversion systems.

\section{Bioconversion to Produce Fertilizers}

The chemical and physical properties of insect frass used as a fertilizer are compatible to other commercial products (Salomone et al. 2017). For example, in one study the growth rate and chemical composition of cabbages grown using black soldier fly frass were identical to commercial fertilizers (Choi et al. 2009). Similarly, onion production was identical for both insect frass and compost amendments (Zahn 2017). This may be due to the added ammonia $\left(\mathrm{NH}_{4}^{+}\right)$from nitrogen in insect 


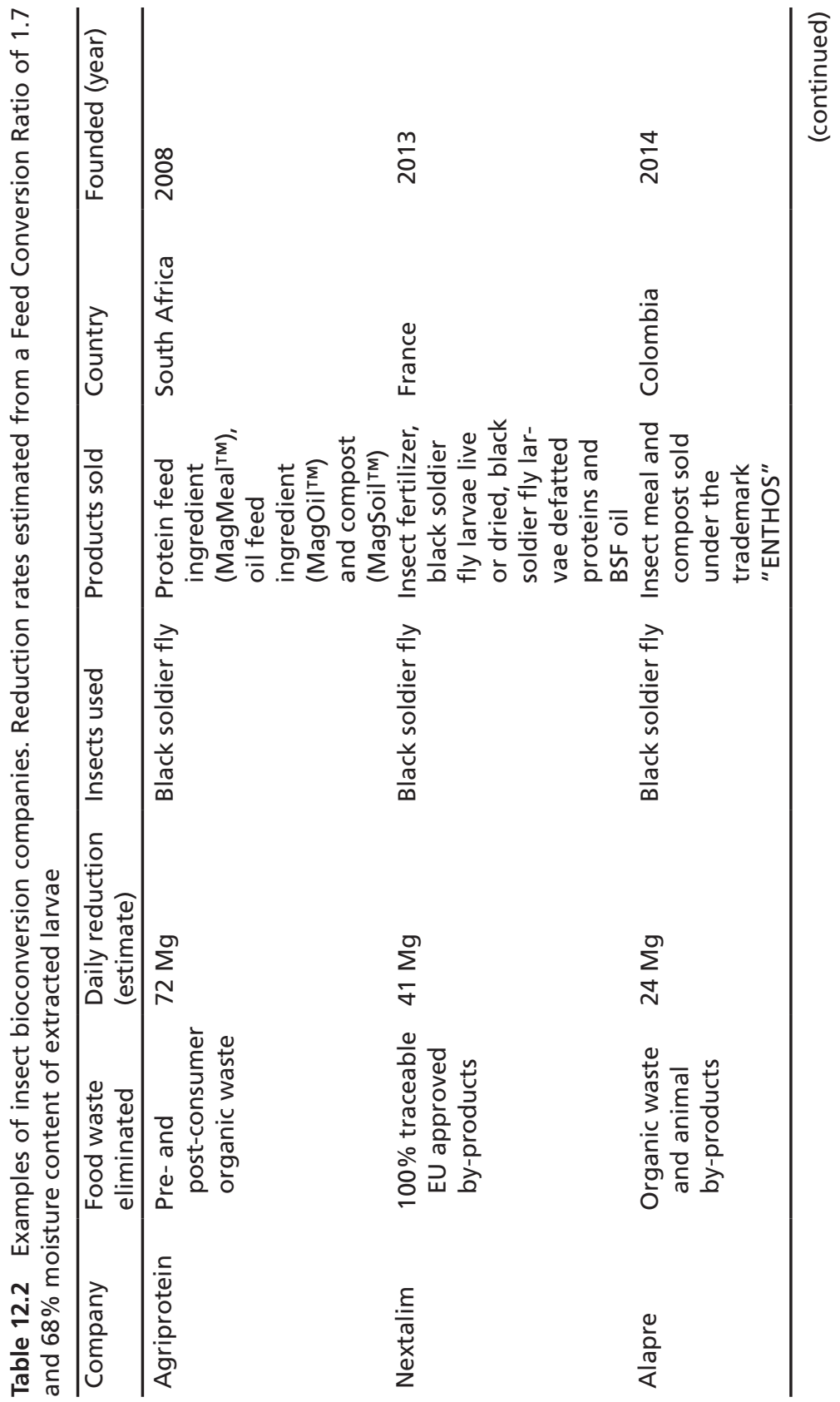




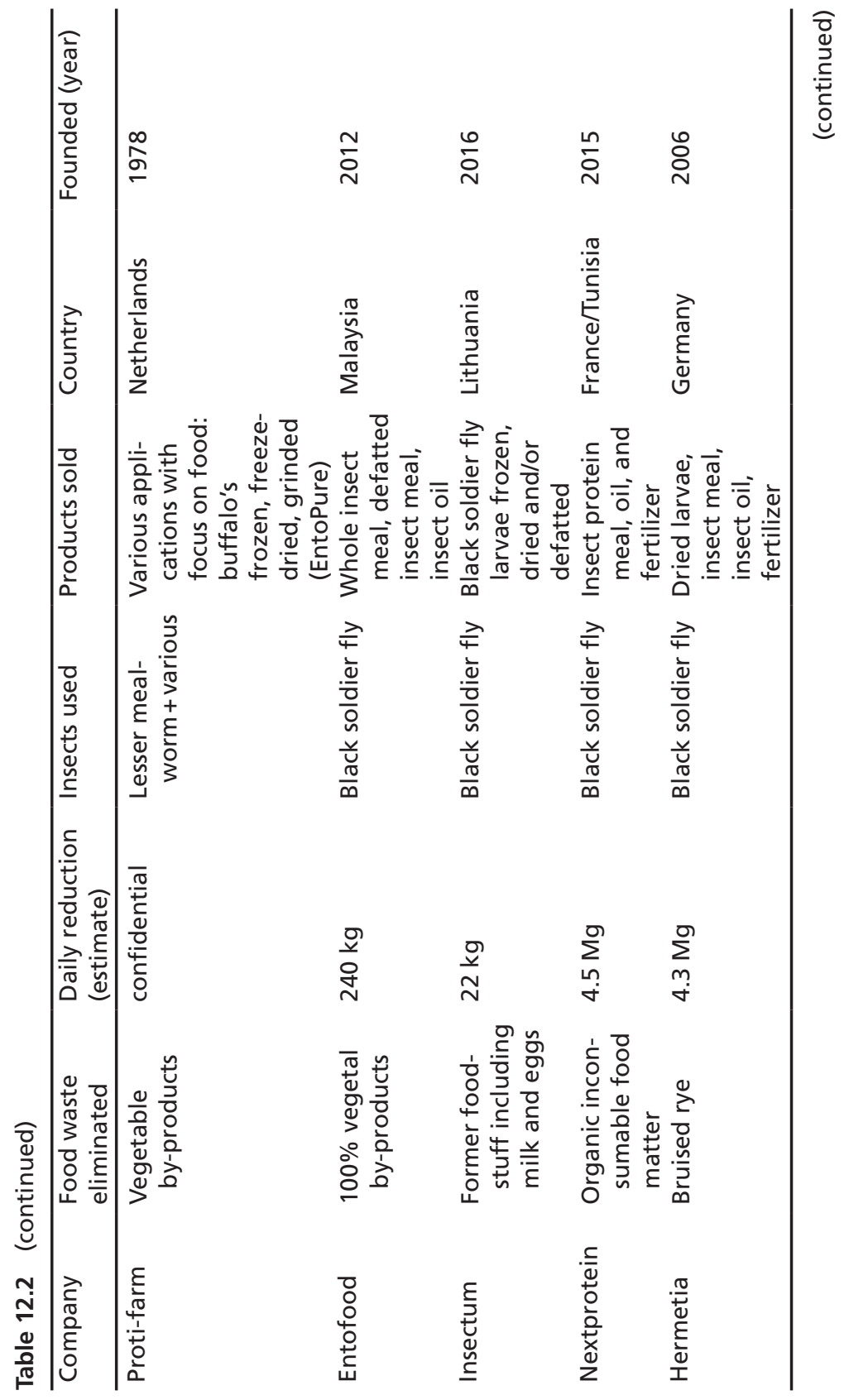




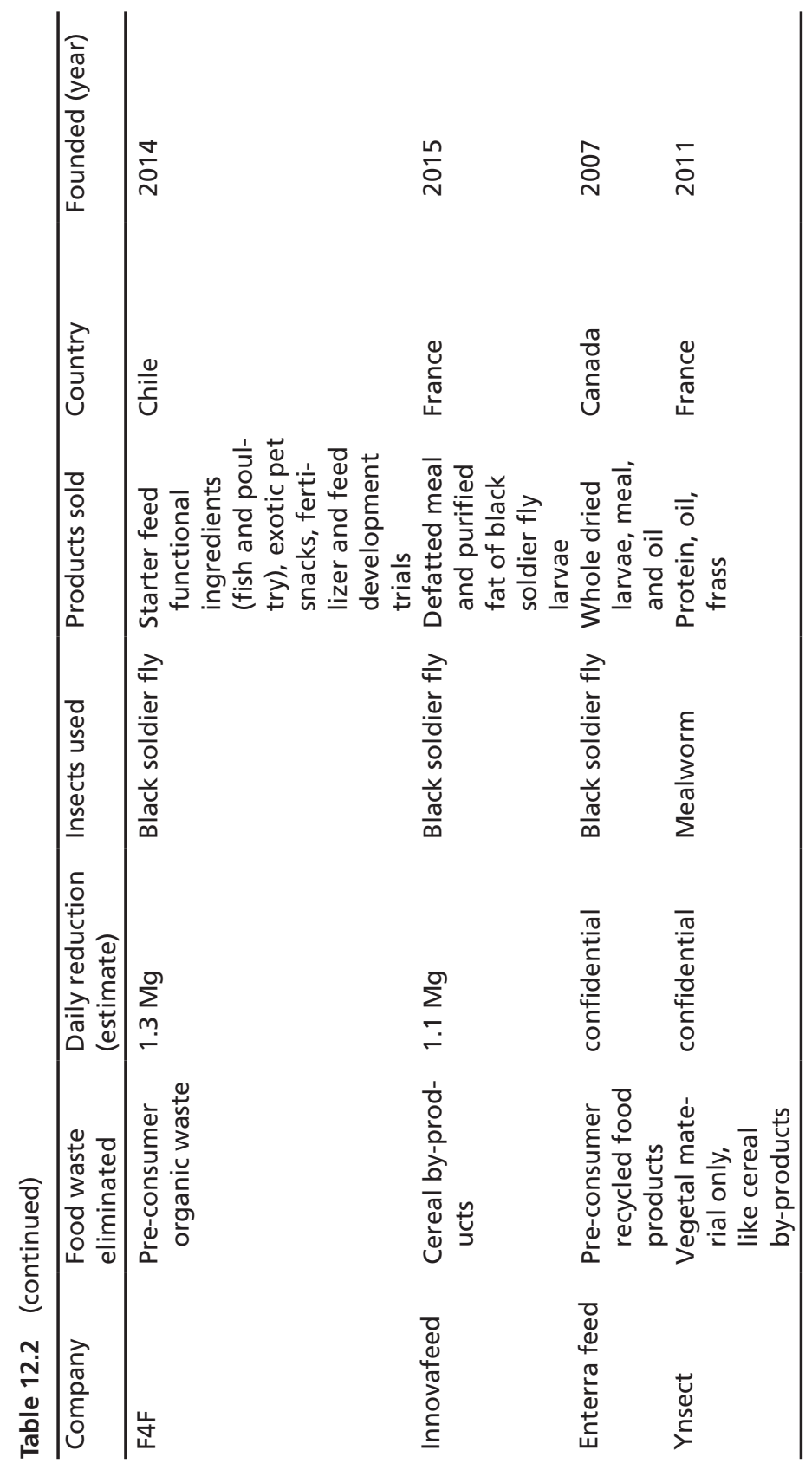


frass, which has been shown to increase fivefold relative to the non-fertilized plants (Green and Popa 2012). In addition, benefits of insect frass compost include reduction of pathogenic microbes and pesticides (Lalander et al. 2016). However, there are concerns that heavy metals may accumulate in the frass of some insects (Diener et al. 2015).

\section{Bioconversion for Biodiesel}

Biodiesel is a promising non-fossil fuel; however, concerns about the resources diverted for its production have sparked debate over a reliance on oilseeds, which require large tracts of arable land and impact food prices. Insects are an alternative source for generating precursors for biodiesel (fats and oils), due to immature insect's predisposal for sequestering high energy fat prior to pupating into adults (Manzano-Agugliaro et al. 2012). In addition, food wastes that are naturally high in fat such as palm oil cake and restaurant waste may be used as a feedstock with the added benefit of reducing the food waste problem while generating sustainable biodiesel. The methodology for producing biodiesel from insects is similar to producing biodiesel from other biological fat sources (Fig. 12.3) (Tyson and McCormick 2006).

Fat contents harvested from insects vary between species, food waste source, and development stage-with the larval stage containing the highest fat content (Manzano-Agugliaro et al. 2012). The immatures of many species have fat contents above $25 \%$, with some in excess of $77 \%$ (moth, Phassus triangularis) (Manzano-Agugliaro et al. 2012). Biodiesel yields can be doubled by first pre-extracting fats from the food waste,

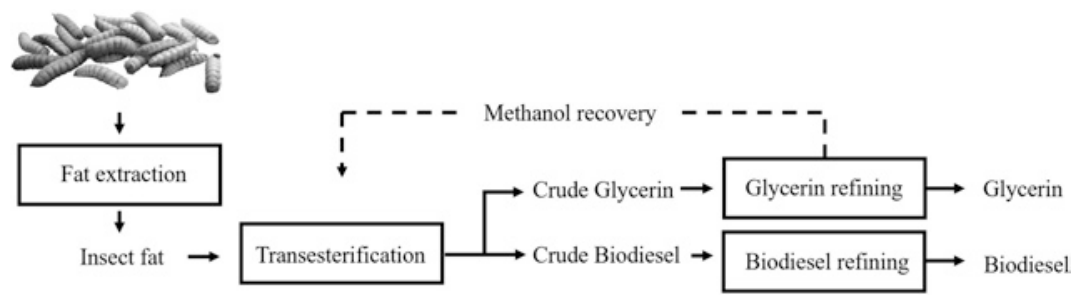

Fig. 12.3 Representative process for production of insect biodiesel 
then feeding the post-extraction remains (solid residual fraction) to insect immatures that are later harvested (Yang et al. 2012; Zheng, Li, et al. 2012). Examples of insects used for biodiesel production include; black soldier fly larvae with added microbes (Rid-X) to convert rice straw $(30 \%)$ and restaurant waste $(70 \%)$, producing $43.8 \mathrm{~g}$ of biodiesel from $1 \mathrm{~kg}$ of waste (Zheng, Li, et al. 2012); yellow mealworm larvae fed decaying vegetables and dry leaves, producing $34.2 \mathrm{~g}$ of biodiesel from $234.8 \mathrm{~g}$ of dried mealworm larval biomass (Zheng et al. 2013); yellow mealworms fed fruit waste and palm oil cake (Leong et al. 2016); latrine fly larvae (Chrysomya megacephala Fabricius) and common housefly (Musca domestica), fed restaurant waste were $-24 \%$ and $-20-35 \%$ oil by dry weight, respectively; flesh fly (Boettcherisca peregrine) fed solid residual fraction of restaurant waste ( $-31 \%$ oil by weight) (Yang et al. 2012). Finally, indicative of the interwoven utility of insect-based bioconversion, one study found waste corn cobs too lignified for direct consumption by black soldier fly larvae were first fermented anaerobically, then given to black soldier fly larvae to make biodiesel—resulting in $87 \mathrm{~L}$ of biogas and $3 \mathrm{~g}$ of biodiesel from $400 \mathrm{~g}$ of corncobs (Li et al. 2015). In conclusion, many steps in insect-based bioconversion of food waste can be used for extraction of fuel sources, providing an alternative to our finite fossil fuel resources.

\section{Bioconversion for Food and Feed}

Human populations are expected to exceed 9 billion before the next century; this will accompany a $60-70 \%$ increase in consumption of animal products (Godfray et al. 2010). Insect-based bioconversion of food waste has the potential for supplementing future protein demands and is an extremely underutilized resource (van Huis 2013). As such, multiple agencies including the FAO, European Union, and U.S. Department of Agriculture encourage the use of insect protein as a logical component for feeding future populations (FAO 2017; Mlcek et al. 2014). However, despite their support, current legislative and oversite infrastructure are underdeveloped for human consumption (EFSA 2015) (see section 'Regulations'). Instead, insect protein is entering 
markets as animal feed, and a growing number of companies use food waste as the feedstock to sustain their operations (Table 12.2).

For animal feeds, the most well studied and commonly used species are black soldier fly larvae, house fly, mealworms, and crickets. Black soldier fly larvae are an especially lucrative feed source, rich in protein and fat, with faster development than other species used for bioconversion (Wang and Shelomi 2017). When ground into insect meal they may be used as a replacement for soya- and fishmeals in many animal feeds. Studies have shown that they are suitable for monogastric animals such as pigs, poultry, freshwater prawns, and some fish species, but not suitable for alligators, some frogs, or ruminants (cows) (Makkar et al. 2014). Larvae fed fish offal from processing plants were on average $30 \%$ lipid, of which $3 \%$ was omega-3 fatty acids (St-Hilaire et al. 2007). Table 12.1 lists a wide range of food wastes used as feedstock for black soldier fly larvae (and other insects) processed into animal feed. A life cycle assessment from one pilot bioconversion facility employing black soldier fly larvae for food waste treatment found 10 megagram $(\mathrm{Mg})$ tonnes of food waste input, generated $0.3 \mathrm{Mg}$ of dried larvae and 3.3 Mg of compost (Salomone et al. 2017). These results are consistent with figures provided from large full-scale operations such as Agriprotein and Nextalim (Table 12.2).

In animal production, comparison of inputs to outputs is referred to as the Feed Conversion Ratio (FCR), with the inverse being the Conversion of Ingested food (ECI) (Waldbauer 1968). Low FCRs indicate higher efficiencies and therefore conversion of the food waste into animal biomass. The literature on conventional livestock feed often uses the FCR, which we will also use to compare insects to other livestock. Studies have found the following FCRs for insects: black soldier fly larvae $=1.4-2.6$, mealworms $=4.1-19.1$, and crickets $=2.3-10.0$ (Oonincx et al. 2015). In comparison, conventional livestock FCRs are: poultry $=2.3$, pork $=4.0$, and beef $=8.8$ (Wilkinson 2011). This suggests, it takes a larger quantity of feed to produce a $\mathrm{kg}$ of beef or pork than it takes to produce a $\mathrm{kg}$ of insects. For example, if $100 \mathrm{~kg}$ of restaurant food waste was fed to black soldier fly larvae, chickens, or a cow, the food waste would yield $58 \mathrm{~kg}$ of black soldier fly larvae, $25 \mathrm{~kg}$ of chicken, or $2.9 \mathrm{~kg}$ of beef. It should be noted that the FCR of 
insects can be highly variable depending on the source feedstock and density of insect populations. However, using average FCR of black soldier fly larvae, we can assess how much income would be generated per unit of food waste. For example, assuming an FCR for black soldier fly larvae of 1.7 , a filled refuse truck $\left(21 \mathrm{~m}^{3}\right.$,) with $50 \mathrm{Mg}$ of food waste, yields $-29 \mathrm{Mg}$ of prepupae (62\% moisture content), which can be dried into $-11 \mathrm{Mg}$ of dry larvae (Diener et al. 2009). At the price of $995 € \cdot \mathrm{Mg}^{-1}\left(1131 \$ \cdot \mathrm{Mg}^{-1}\right)$, this would yield $€ 11,000(\$ 12,500)$ (Salomone et al. 2017) each truckload. Insect-based bioconversion of food waste therefore is an appealing opportunity for producing marketable proteins, while simultaneously mitigating the negative impacts of food waste.

\section{Regulations}

Commercialization of output materials from insect bioconversion requires a high degree of confidence in their safety. Due to the novelty of industrially mass-produced insects for food and feed, risks of associated contaminants entering the food chain warrant investigation and oversight. In anticipation of new products making their way into European markets, the European Food Standards Agency (EFSA) has published an opinion on the risk profile of insects as food and feed, concluding that food and feed products should pose no greater threat than products already on the market (EFSA 2015). Further, the agency highlighted the need for continued research in microbial, chemical, and allergenic hazards, as well as impacts on processing, storage, and environmental hazards (EFSA 2015). This has been welcoming news for stakeholders of insect-derived products, demonstrating increased legitimacy and legislative consistency for the growing economic sector. However, significant legal hurdles remain, for example, the European Union prohibits insect meal as feed for pigs and poultry, but not aquiculture (Regulation EC No. 999/2001), it is prohibited to use catering waste as feed stock (Regulation EC No. 1069/2009); and insects must be "slaughtered" off-site (Regulation EC No. 1099/2002). In addition, the United States and European Union consider some insects as 
"mini-livestock", thus affording protections against inhumane slaughter (Vantomme et al. 2012).

Research into the chemical safety concerns has been mostly positive, for example many insects accumulate chemical contaminants (pesticides, heavy metals, pharmaceuticals, dioxins, and mycotoxins) below recommended maximum concentrations suggested by the European Commission and World Health Organization (Charlton et al. 2015; Lalander et al. 2016; Purschke et al. 2017). However, examples of toxic heavy metal accumulation have been documented for house fly (i.e. cadmium) (Charlton et al. 2015), blowfly (Calliphora sp.) (mercury) (Nuorteva and Nuorteva 1982), and black soldier fly (lead) (Purschke et al. 2017). Recommended measures ensuring end product safety include monitoring the food waste feedstock, as well as the insects produced (Purschke et al. 2017). In the case of microbial contamination, highly competitive "pestiferous" species such as black soldier fly secretes antimicrobial compounds into the wastes they feed in (Park et al. 2014; Sheppard et al. 2007). These secretions limit and can even prevent hazardous pathogens like E. coli and Salmonella in the waste (Erickson et al. 2004; Lalander et al. 2015). These antimicrobial properties are highly beneficial for the bioconversion of municipal food waste, due to the wastes' heterogeneous states of decomposition.

Regulations on producing animal feeds were not designed with insect meals in mind. As laws come under review, amendments likely will be added to permit more biologically informed oversight. Overall, insects used for food and feed are considered safe (Belluco et al. 2013). This is consistent with insects' role as an integral component of many animals diets, and humans long history of consuming insects both intentionally and inadvertently (Center for Food Safety \& Applied Nutrition 1995; DeFoliart 1992).

\section{Conclusion}

Insect-based bioconversion of food waste offers an exciting vision for a more sustainable future and for novel paths to sustainable food production and food security. Insect-based bioconversion is particularly 
exciting, because it enables food and feed production in densely populated areas (urban settings) and therefore goes against the common notion that urban development and food production are antagonistic. After many years of advocating the potential of developing industrial scale operations to tackle food waste (van Huis 2013; Wang and Shelomi 2017), insect-based bioconversion companies are now being established and their throughput is reaching scale, becoming profitable, and moving into international markets. This next decade will see considerable growth in this sector, bringing jobs, novel commodities, new inputs to the food and feed supply, and ultimately reduction and reuse of food waste streams currently considered problematic. For this vision to materialize, research is needed to find more food waste-to-insect pairings, as well as selective breeding to develop specialized insect strains. Both are needed to increase capacity and to maximize the potential benefits of using insect-based bioconversion of food waste. The risks posed by the development of high-performance insect strains for food waste elimination are small, as many of the commercial insect species used for bioconversion are naturally occurring globally (mealworms, black soldier fly). Research is needed to bridge the gap between enterprises engaged in insect-based bioconversion and the regulatory agencies keeping us safe. More studies on the safety of insect-derived products are likely to lead to biologically informed policy. With the proper checks, insect-based bioconversion of food waste has the potential to serve as a powerful tool to eliminate food waste, create jobs, and provide an environmentally friendly source of protein to help feed our ever-growing global population.

Acknowledgements This chapter was written based on partial funding from the United States Department of Agriculture's (USDA) programme for Western Sustainable Agriculture Research and Education (WSARE) (subaward: 200592-446), as well as partial funding from the U.S. Department of Agriculture's (USDA) Agricultural Marketing Service through grant 18-00001028-SC. Its contents are solely the responsibility of the authors and do not necessarily represent the official views of the USDA. 


\section{References}

Alves, A. V., Sanjinez-Argandoña, E. J., Linzmeier, A. M., Cardoso, C. A. L., \& Macedo, M. L. R. (2016). Food value of mealworm grown on Acrocomia aculeata pulp flour. PLoS ONE, 11(3), e0151275.

Ambuko, J. (2014). Food losses and waste in the context of sustainable food systems. In RUFORUM Fourth Biennial Conference, Maputo, Mozambique, 19-25 July 2014 (pp. 387-388). RUFORUM.

Anankware, P. J., Fening, K. O., Osekre, E., \& Obeng-Ofori, D. (2015). Insects as food and feed: A review. International Journal of Agricultural Research and Review, 3(1), 143-151.

Barry, T. (2004). Evaluation of the economic, social, and biological feasibility of bioconverting food wastes with the black soldier fly (Hermetia illucens). Doctoral dissertation, University of Texas, Austin, Texas.

Belluco, S., Losasso, C., Maggioletti, M., Alonzi, C. C., Paoletti, M. G., \& Ricci, A. (2013). Edible insects in a food safety and nutritional perspective: A critical review. Comprehensive Reviews in Food Science and Food Safety, 12(3), 296-313.

Bonso, N. K. (2013). Bioconversion of organic fraction of solid waste using the larvae of the black soldier fly (Hermetia illucens). Master's thesis, Kwame Nkrumah University of Science and Technology, Kumasi, Ghana. http:// ir.knust.edu.gh/xmlui/bitstream/handle/123456789/5589/MSC-thesis\%20 final $\% 202013 \% 2 \mathrm{c} \% 20 \mathrm{Nana} \% 20$ Kobea $\% 20$ Bonso $\% 20$.pdf?sequence= 1 . Accessed on 26.2.2019.

Brar, S. K., Verma, M., Tyagi, R. D., Valéro, J. R., \& Surampalli, R. Y. (2008). Wastewater sludges as novel growth substrates for rearing codling moth larvae. World Journal of Microbiology \& Biotechnology, 24(12), 2849-2857.

Carroll, S. P., Klassen, S. P., \& Dingle, H. (1998). Rapidly evolving adaptations to host ecology and nutrition in the soapberry bug. Evolutionary Ecology, 12(8), 955-968.

Center for Food Safety \& Applied Nutrition (US). (1995). The food defect action levels: Levels of natural or unavoidable defects in foods that present no health hazards for humans. Washington, DC: Department of Health and Human Services, Public Health Service, Food and Drug Administration, Center for Food Safety and Applied Nutrition. https:/www.fda.gov/ Food/GuidanceRegulation/GuidanceDocumentsRegulatoryInformation/ SanitationTransportation/ucm056174.htm. Accessed on 28.2.2019. 
Charlton, A. J., Dickinson, M., Wakefield, M. E., Fitches, E., Kenis, M., Han, R., et al. (2015). Exploring the chemical safety of fly larvae as a source of protein for animal feed. Journal of Insects as Food and Feed, 1(1), 7-16.

Cheng, Y. K. (2016). Black soldier fly bioconversion for food waste recycling: improved residue separation method and increased larval survival rate. Doctoral dissertation, The Hong Kong University of Science and Technology, Hong Kong, China. http://repository.ust.hk/ir/ Record/1783.1-86623. Accessed on 26.2.2019.

Cheng, J. Y., Chiu, S. L., \& Lo, I. M. (2017). Effects of moisture content of food waste on residue separation, larval growth and larval survival in black soldier fly bioconversion. Waste Management, 67, 315-323.

Choi, Y.-C., Choi, J.-Y., Kim, J.-G., Kim, M.-S., Kim, W.-T., Park, K.-H., et al. (2009). Potential usage of food waste as a natural fertilizer after digestion by Hermetia illucens (Diptera: Stratiomyidae). International Journal of Industrial Entomology, 19(1), 171-174.

DeFoliart, G. R. (1992). Insects as human food: Gene DeFoliart discusses some nutritional and economic aspects. Crop Protection, 11(5), 395-399.

De Jong, G., \& Bijma, P. (2002). Selection and phenotypic plasticity in evolutionary biology and animal breeding. Livestock Production Science, 78(3), $195-214$.

Diener, S., Zurbrügg, C., \& Tockner, K. (2009). Conversion of organic material by black soldier fly larvae: Establishing optimal feeding rates. Waste Management and Research, 27(6), 603-610.

Diener, S., Zurbrügg, C., \& Tockner, K. (2015). Bioaccumulation of heavy metals in the black soldier fly, Hermetia illucens and effects on its life cycle. Journal of Insects as Food and Feed, 1(4), 261-270.

Dossey, A. T., Morales-Ramos, J. A., \& Rojas, M. G. (2016). Insects as sustainable food ingredients: Production, processing and food applications. Cambridge, MA: Academic Press.

D’Souza, C., Taghian, M., Lamb, P., \& Peretiatko, R. (2007). Green decisions: Demographics and consumer understanding of environmental labels. International Journal of Consumer Studies, 31(4), 371-376.

Erickson, M. C., Islam, M., Sheppard, C., Liao, J., \& Doyle, M. P. (2004). Reduction of Escherichia coli O157: H7 and Salmonella enterica serovar enteritidis in chicken manure by larvae of the black soldier fly. Journal of Food Protection, 67(4), 685-690.

European Food Safety Authority Scientific Committee (EFSA). (2015). Risk profile related to production and consumption of insects as food and feed. European Food Safety Authority Journal, 13(10), 4257. 
FAO. (2017). The future of food and agriculture. Trends and challenges. Food and Agriculture Organization of the United Nations. http://www.fao.org/3/ai6583e.pdf. Accessed on 26.2.2019.

Garlapow, M. E., Huang, W., Yarboro, M. T., Peterson, K. R., \& Mackay, T. F. (2015). Quantitative genetics of food intake in Drosophila melanogaster. PLoS ONE, 10(9), e0138129.

Godfray, H. C. J., Beddington, J. R., Crute, I. R., Haddad, L., Lawrence, D., Muir, J. F., et al. (2010). Food security: The challenge of feeding 9 billion people. Science, 1185383.

Green, T. R., \& Popa, R. (2012). Enhanced ammonia content in compost leachate processed by black soldier fly larvae. Applied Biochemistry and Biotechnology, 166(6), 1381-1387.

Hogsette, J. A. (1992). New diets for production of house flies and stable flies (Diptera: Muscidae) in the laboratory. Journal of Economic Entomology, 85(6), 2291-2294.

Jensen, K., Kristensen, T. N., Heckmann, L.-H., \& Sørensen, J. G. (2017). Breeding and maintaining high-quality insects. Insects as food and feed (pp. 175-198). Wageningen Academic Publishers: Wageningen.

Lalander, C. H., Fidjeland, J., Diener, S., Eriksson, S., \& Vinnerås, B. (2015). High waste-to-biomass conversion and efficient Salmonella spp. reduction using black soldier fly for waste recycling. Agronomy for Sustainable Development, 35(1), 261-271.

Lalander, C., Senecal, J., Calvo, M. G., Ahrens, L., Josefsson, S., Wiberg, K., et al. (2016). Fate of pharmaceuticals and pesticides in fly larvae composting. Science of the Total Environment, 565, 279-286.

Lardé, G. (1990). Recycling of coffee pulp by Hermetia illucens (Diptera: Stratiomyidae) larvae. Biological Wastes, 33(4), 307-310.

Leong, S. Y., Kutty, S. R. M., Malakahmad, A., \& Tan, C. K. (2016). Feasibility study of biodiesel production using lipids of Hermetia illucens larva fed with organic waste. Waste Management, 47, 84-90.

Li, W., Li, Q., Zheng, L., Wang, Y., Zhang, J., Yu, Z., et al. (2015). Potential biodiesel and biogas production from corncob by anaerobic fermentation and black soldier fly. Bioresource Technology, 194, 276-282.

Li, Z., Yang, D., Huang, M., Hu, X., Shen, J., Zhao, Z., et al. (2012). Chrysomya megacephala (Fabricius) larvae: A new biodiesel resource. Applied Energy, 94, 349-354.

Li, L., Zhao, Z., \& Liu, H. (2013). Feasibility of feeding yellow mealworm (Tenebrio molitor L.) in bioregenerative life support systems as a source of animal protein for humans. Acta Astronautica, 92(1), 103-109. 
Lim, S. L., Lee, L. H., \& Wu, T. Y. (2016). Sustainability of using composting and vermicomposting technologies for organic solid waste biotransformation: Recent overview, greenhouse gases emissions and economic analysis. Journal of Cleaner Production, 111, 262-278.

Makkar, H. P., Tran, G., Heuzé, V., \& Ankers, P. (2014). State-of-the-art on use of insects as animal feed. Animal Feed Science and Technology, 197, 1-33.

Manurung, R., Supriatna, A., Esyanthi, R. R., \& Putra, R. E. (2016). Bioconversion of Rice straw waste by black soldier fly larvae (Hermetia illucens L.): Optimal feed rate for biomass production. Journal of Entomology and Zoology Studies, 4(4), 1036-1041.

Manzano-Agugliaro, F., Sanchez-Muros, M. J., Barroso, F. G., MartínezSánchez, A., Rojo, S., \& Pérez-Bañón, C. (2012). Insects for biodiesel production. Renewable and Sustainable Energy Reviews, 16(6), 3744-3753.

Miech, P., Berggren, A., Lindberg, J. E., Chhay, T., Khieu, B., \& Jansson, A. (2016). Growth and survival of reared Cambodian field crickets (Teleogryllus testaceus) fed weeds, agricultural and food industry by-products. Journal of Insects as Food and Feed, 2(4), 285-292.

Mlcek, J., Rop, O., Borkovcova, M., \& Bednarova, M. (2014). A comprehensive look at the possibilities of edible insects as food in Europe-A review. Polish Journal of Food and Nutrition Sciences, 64(3), 147-157.

Mutafela, R. N. (2015). High value organic waste treatment via black soldier fly bioconversion: Onsite pilot study. Master's thesis, Royal Institute of Technology, Stockholm, Sweden. https:/www.diva-portal.org/smash/get/ diva2:868277/FULLTEXT02.pdf. Accessed on 26.2.2019.

Nansen, C., Baissac, O., Nansen, M., Powis, K., \& Baker, G. (2016). Behavioral avoidance-will physiological insecticide resistance level of insect strains affect their oviposition and movement responses? PLoS ONE, 11(3), e0149994.

Niu, Y., Zheng, D., Yao, B., Cai, Z., Zhao, Z., Wu, S., et al. (2017). A novel bioconversion for value-added products from food waste using Musca domestica. Waste Management, 61, 455-460.

Nuorteva, P., \& Nuorteva, S.-L. (1982). The fate of mercury in sarcosaprophagous flies and in insects eating them. Ambio, 11, 34-37.

Nyakeri, E. M., Ogola, H. J. O., Ayieko, M. A., \& Amimo, F. A. (2017). Valorisation of organic waste material: Growth performance of wild black soldier fly larvae (Hermetia illucens) reared on different organic wastes. Journal of Insects as Food and Feed, 3(3), 193-202. 
Oonincx, D. G., Van Broekhoven, S., Van Huis, A., \& van Loon, J. J. (2015). Feed conversion, survival and development, and composition of four insect species on diets composed of food by-products. PLoS ONE, 10(12), e0144601.

Ortiz, J. C., Ruiz, A. T., Morales-Ramos, J. A., Thomas, M., Rojas, M. G., Tomberlin, J. K., et al. (2016). Insect mass production technologies. In A. T. Dossey, J. Morales-Ramos, \& M. Guadalupe Rojas (Eds.), Insects as sustainable food ingredients (pp. 153-201). Amsterdam: Elsevier.

Parfitt, J., Barthel, M., \& Macnaughton, S. (2010). Food waste within food supply chains: Quantification and potential for change to 2050. Philosophical Transactions of the Royal Society B: Biological Sciences, 365(1554), 3065-3081.

Park, S.-I., Chang, B. S., \& Yoe, S. M. (2014). Detection of antimicrobial substances from larvae of the black soldier fly, Hermetia illucens (Diptera: Stratiomyidae). Entomological Research, 44(2), 58-64.

Purschke, B., Scheibelberger, R., Axmann, S., Adler, A., \& Jäger, H. (2017). Impact of substrate contamination with mycotoxins, heavy metals and pesticides on the growth performance and composition of black soldier fly larvae (Hermetia illucens) for use in the feed and food value chain. Food Additives \& Contaminants: Part A, 34(8), 1410-1420.

Salomone, R., Saija, G., Mondello, G., Giannetto, A., Fasulo, S., \& Savastano, D. (2017). Environmental impact of food waste bioconversion by insects: Application of life cycle assessment to process using Hermetia illucens. Journal of Cleaner Production, 140, 890-905.

Sheppard, D. C., Newton, G. L., \& Burtle, G. (2007). Black soldier fly prepupae: A compelling alternative to fish meal and fish oil. NOAA-USDA Alternative Feeds Initiative Report. http://www.aquacircle.org/images/pdfdokumenter/udvikling/andre/amerika/Soldier_fly_compelling_alternative_ NOAA-USDA.pdf. Accessed on 28.2.2019.

Smetana, S., Palanisamy, M., Mathys, A., \& Heinz, V. (2016). Sustainability of insect use for feed and food: Life cycle assessment perspective. Journal of Cleaner Production, 137, 741-751.

St-Hilaire, S., Cranfill, K., McGuire, M. A., Mosley, E. E., Tomberlin, J. K., Newton, L., et al. (2007). Fish offal recycling by the black soldier fly produces a foodstuff high in omega-3 fatty acids. Journal of the World Aquaculture Society, 38(2), 309-313.

Suantika, G., Putra, R. E., Hutami, R., \& Rosmiati, M. (2017). Application of compost produced by bioconversion of coffee husk by black soldier fly 
larvae (Hermetia Illucens) as solid fertilizer to lettuce (Lactuca Sativa Var. Crispa). Proceedings of the International Conference on Green Technology, 8(1), 20-26. http://conferences.uin-malang.ac.id/index.php/ICGT/article/ view/376. Accessed on 26.2.2019.

Supriyatna, A., Manurung, R., Esyanthi, R. E., \& Putra, R. E. (2016). Growth of black soldier larvae fed on cassava peel wastes, An agriculture waste. Journal of Entomology and Zoology Studies, 4(6), 161-165.

Tinder, A. C., Puckett, R. T., Turner, N. D., Cammack, J. A., \& Tomberlin, J. K. (2017). Bioconversion of sorghum and cowpea by black soldier fly (Hermetia illucens (L.)) larvae for alternative protein production. Journal of Insects as Food and Feed, 3(2), 121-130.

Tyson, K. S., \& McCormick, R. L. (2006). Biodiesel handling and use guidelines. U.S. Department of Energy. https://web.archive.org/ web/20170119154306/http://www.nrel.gov/docs/fy06osti/40555.pdf. Accessed on 26.2.2019.

van Dyk, J. S., Gama, R., Morrison, D., Swart, S., \& Pletschke, B. I. (2013). Food processing waste: Problems, current management and prospects for utilisation of the lignocellulose component through enzyme synergistic degradation. Renewable and Sustainable Energy Reviews, 26, 521-531.

van Huis, A. (2013). Potential of insects as food and feed in assuring food security. Annual Review of Entomology, 58, 563-583.

van Huis, A., \& Oonincx, D. G. (2017). The environmental sustainability of insects as food and feed. A review. Agronomy for Sustainable Development, $37(5), 43$.

Vantomme, P., Mertens, E., van Huis, A., \& Klunder, H. (2012). Assessing the potential of insects as food and feed in assuring food security: Summary report. Food and Agricultural Organization of the United Nations. Forestry Department, Rome, Italy. http://www.fao.org/3/an233e/an233e00.pdf. Accessed on 28.2.2019.

Veldkamp, T., Van Duinkerken, G., Van Huis, A., Lakemond, C. M. M., Ottevanger, E., Bosch, G., et al. (2012). Insects as a sustainable feed ingredient in pig and poultry diets: A feasibility study=Insecten als duurzame diervoedergrondstof in varkens-en pluimveevoeders: een haalbaarheidsstudie. Lelystad: Wageningen UR Livestock Research.

Waldbauer, G. P. (1968). The consumption and utilization of food by insects. In Advances in insect physiology (Vol. 5) (pp. 229-288). Amsterdam: Elsevier. Wang, H., Rehman, K., Liu, X., Yang, Q., Zheng, L., Li, W., et al. (2017). Insect biorefinery: A green approach for conversion of crop residues into biodiesel and protein. Biotechnology for Biofuels, 10(1), 304. 
Wang, Y.-S., \& Shelomi, M. (2017). Review of black soldier fly (Hermetia illucens) as animal feed and human food. Foods, 6(10), 91.

Wilkinson, J. M. (2011). Re-defining efficiency of feed use by livestock. Animal, 5(7), 1014-1022.

Yang, S., Li, Q., Zeng, Q., Zhang, J., Yu, Z., \& Liu, Z. (2012). Conversion of solid organic wastes into oil via Boettcherisca peregrine (Diptera: Sarcophagidae) larvae and optimization of parameters for biodiesel production. PLoS ONE, 7(9), e45940.

Zahn, N. H. (2017). The effects of insect frass created by Hermetia illucens on spring onion growth and soil fertility. Bachelor's thesis, University of Stirling, Stirling, Great Britain.

Zheng, L., Hou, Y., Li, W., Yang, S., Li, Q., \& Yu, Z. (2012). Biodiesel production from rice straw and restaurant waste employing black soldier fly assisted by microbes. Energy, 47(1), 225-229.

Zheng, L., Hou, Y., Li, W., Yang, S., Li, Q., \& Yu, Z. (2013). Exploring the potential of grease from yellow mealworm beetle (Tenebrio molitor) as a novel biodiesel feedstock. Applied Energy, 101, 618-621.

Zheng, L., Li, Q., Zhang, J., \& Yu, Z. (2012). Double the biodiesel yield: Rearing black soldier fly larvae, Hermetia illucens, on solid residual fraction of restaurant waste after grease extraction for biodiesel production. Renewable Energy, 41, 75-79.

Open Access This chapter is licensed under the terms of the Creative Commons Attribution 4.0 International License (http://creativecommons. org/licenses/by/4.0/), which permits use, sharing, adaptation, distribution and reproduction in any medium or format, as long as you give appropriate credit to the original author(s) and the source, provide a link to the Creative Commons license and indicate if changes were made.

The images or other third party material in this chapter are included in the chapter's Creative Commons license, unless indicated otherwise in a credit line to the material. If material is not included in the chapter's Creative Commons license and your intended use is not permitted by statutory regulation or exceeds the permitted use, you will need to obtain permission directly from the copyright holder.

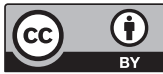

